Немцев М.Ю. В чем ошибся Мамардашвили и что извратил Ильенков? : рецензия на книгу о советской философии // Философия. Журнал Высшей школы экономики. 2019. - T. III, № 4. - C. 251-275.

\title{
Михаил НЕмцев*
}

\section{В ЧЕМ ОШИБСЯ МАМАРААШВИЛИ И ЧТО ИЗВРАТИЛ ИЛЬЕНКОВ?**}

\section{РЕЦЕНЗИЯ НА КНИГУ О СОВЕТСКОЙ ФИЛОСОФИИ}

ПУЩАЕВ Ю. В. ФИЛОСОФИЯ СОВЕТСКОГО ВРЕМЕНИ : М. МАМАРААШВИЛИ И Э. ИЛЬЕНКОВ (ЭНЕРГИИ ПРИТЯЖЕНИЯ И ОТТАЛКИВАНИЯ). - М. : ИНИОН РАН, 2018.

DOI: $10.17323 / 2587-8719-2019-4-251-275$.

Дискуссии о том, говорить ли о «философии в Советском Союзе», или все же лучше называть ее «советской философией» периодически возобновляются все постсоветское время. Советская история неотъемлемо связана с советской властью, а та-с марксизмом-ленинизмом. Эта «официальная» философиея себя полностью дискредитировала. Поэтому само словосочетание «советская философия» и сейчас вызывает у многих неприятные чувства. Те, кто стремится подчеркнуть, что в Советском Союзе все-таки была своя «настоящая», полнокровная философия, считают важным аргументом тот факт, что несмотря на цензуру, давление официоза и т. д., в СССР все же появлялись яркие и безусловно самостоятельные мыслители. Чаще всего при этом называют именно эти два имени: Мераб Мамардашвили и Эвальд Ильенков. Рассматриваемая книга уже самим названием предполагает сравнение и сопоставления. Уже поэтому она должна привлечь к себе интерес всех, кого интересуют эти двое и этот период философии.

Автор этой книги пристрастен. Он относится к Ильенкову и Мамардашвили по-разному. Первый из них - страстный атеист, коммунист, второй - антикоммунист с интересом к христианству. При этом об Ильенкове Пущаев пишет с большей отстраненностью, иногда даже и с явной человеческой симпатией, а к Мамардашвили он заметно

*Немцев Михаил Юрьевич, к. филос. н., магистр гендерных исследований; доцент, Российский экономический университет им. Г. В. Плеханова, Московский международный университет, nemtsev.m@gmail.com.

** (C) Немцев, М. Ю. () Философия. Журнал Высшей школы экономики. 
более суров. Почему? Ильенков выступает для автора в качестве точки отсчета. И не только потому, что Мамардашвили отталкивался от него (по собственному признанию в позднем биографическом интервью «Начало всегда исторично, т. е. случайно», откуда это слово, видимо, и перекочевало в текст Пущаева $\left.{ }^{1}\right)$, но вовсе не Ильенков от Мамардашвили. Автор явно симпатизирует Ильенкову, перенося на него свою симпатию к советскому государству. Он не скрывает своего православного мировоззрения, но заступается за «советскую цивилизацию» перед Мамардашвили как ее внутренним противником. Странным образом соединяя православие и ностальгию по советскому (распространенность этого сочетания не делает ее менее противоречивым), автор оценивает философов, о которых пишет, по критерию их отношения к советскому государству. Даже безбожные, но по-своему убежденные коммунисты Пущаеву ближе, чем посткоммунистические либералы. По его убеждению, их приход был подготовлен советскими либералам, такими как Мамардашвили. Обличение Мамардашвили в антисоветской агитации и пропаганде столь важно для Пущаева, что он вновь и вновь возвращается к этой теме, не позволяя читателю забыть, о чем в конечном итоге идет речь. Он симпатизирует атеисту Ильенкову, простив тому безбожие за то, что Ильенков был настоящим советским человеком, «марксистско-ленинским идеалистом» (Пущаев, 2018: 31), но не интересовавшемуся христианством и ссылавшемуся на евангелие Мамардашвили. Ведь тот был, по убеждению Пущаева, «либералом», а значит антисоветчиком и даже русофобом. Пущаев явно следует обычной норме постсоветского употребления слова «либерал», когда «либерализм» узнается по «западничеству», и подразумевает не только «антикоммунизм». но и так называемую «русофобию». Поэтому историко-философская работа постоянно норовит превратиться в некое сведение счетов с «неуместным, вредоносным» (там же) либерализмом девяностых. Это придает некоторым местам книги особенно яркую публицистическую интонацию. Заметная часть текста, особенно во второй части книги, посвящена дискредитации антисоветских и националистических взглядов Мамардашвили.

${ }^{1}$ Точная цитата: «...я, [...] воспользовавшись наработанным Ильенковым, шел дальше в своих собственных представлениях, критически отталкиваясь от стиля и решений, им предложенных. Потом это отталкивание совпало с существовавшей полемикой...» (Мамардашвили, 2015). 
Итак, в Мамардашвили он сразу же опознает либерала-и в его лице сводит счеты с постсоветским либерализмом. Сообщая читателю, что Мамардашвили был «либералом» как само собой разумеющийся факт без предварительного историко-философского анализа и пояснений, он встраивает взгляды Мамардашвили в общий контекст позднесоветского «западничества». И яростно критикует весь этот контекст, причем достается не только самому Мамардашвили, но и его друзьям. Полагая, что политическая философия обоих рассматриваемых мыслителей выводима из их онтологии и гносеологии, он их оценивает по плодам. Появление такой книги показывает, что споры 1990-х о «либерализме» совсем еще даже не прекратились, - но при этом содержательно почти не продвинулись.

Книга состоит из трех разделов. В первом рассматриваются онтология и гносеология обсуждаемых авторов. Второй раздел посвящен анализу политических взглядов преимущественно Мамардашвили, которому вообще уделяется в книге сравнительно больше внимания. Третий, «История и теория Загорского эксперимента», включает в себя исследование известной работы Ильенкова со слепоглухонемыми детьми, и представляет собой развернутый ответ на вопрос «Врал ли Ильенков?». Пущаев не обращается к вышедшим в последние несколько лет исследованиям, посвященным Ильенкову и Мамардашвили. В книге он, скорее, основывается на материале своих статей, опубликованных ранее.

Необходимо отметить, что выбор источников для анализа эволюции взглядов Мамардашвили в любой подобной работе в принципе требует специального обоснования. До настоящего времени именно эволюция его взглядов мало изучена. Идеи Ильенкова адекватно представлены уже прижизненно опубликованными работами ${ }^{2}$ В отличие от Ильенкова, важные произведения «позднего» Мамардашвили были опубликованы только недавно, включая объемные курсы лекций 1970-1980-х годов. Юрий Пущаев не уделяет должного внимания этим работам, хотя указывает их в библиографии. Фактически его источники-это три, опубликованных еще в 1990-х Ю. Сенокосовым, лекционных курса «Кантианские вариации», «Картезианские размышления» и «Лекции о Прусте», плюс известный сборник статей «Как я понимаю философию». О «Лекциях о Прусте» автор пишет, что эта книга «многими

${ }^{2}$ Жаль только, что столь важный для понимания генезиса его взглядов текст, как недавно изданная реконструкция «Тезисов о предмете философии» (Ильенков, Коровиков, 2016) осталась неиспользованной автором этого исследования. 
оправданно считается важнейшим произведением Мамардашвили» (Пущаев, 2018: 156). Тут же по ссылке в подтверждение приводится мнение В. Подороги. Затем эти же лекции прямо названы «пожалуй, главной» книгой (там же: 247). Хотелось бы, однако какого-то историко-философского обоснования выбора именно этих книг в качестве основного материала. Понятно, что именно эти три курса были наиболее популярны у любителей философии Мамардашвили в период, когда они уже были опубликованы и доступны, а другие поздние работы-еще нет. Но ведь книга готовилась к публикации уже после появления новых публикаций, кстати, учтенных и в библиографии и в основном тексте ${ }^{3}$. Теперь, когда у исследователей имеется значительный корпус работ Мамардашвили, выбор лишь нескольких из них требует специального обоснования.

При этом читатели, сами того не ожидая, оказываются в источниковедческой ловушке. Ключевыми для понимания философии Мамардашвили представляются тексты, которые он не писал (хотя текст «Кантианские вариации» он готовил для публикации), в то время как написанные им в тот же период работы оказываются как бы в стороне. Тем самым косвенно подтверждается распространенное (и совершенно неверное) представление о Мамардашвили как о философе исключительно «устном», писавшем мало, неохотно, а публиковавшем и того меньше.

Конечно, вопрос о том, какие работы Мамардашвили брать в качестве наиболее репрезентативных, довольно сложен. Принимая разделение его творчества на «раннее» и «позднее», Пущаев полагает его «ранними» работами тексты, созданные уже в конце 1960-х - начале 1970-х, полностью оставляя без внимания статьи предыдущего периода, когда Мамардашвили развивал диалектическую логику (Хромченко, 2004), пересказывал Гегеля и критиковал экзистенциалистов. Но если обратить на эти работы внимание, то критерии разделения работ Мамардашвили на «ранние» и «поздние» требуют уточнения. Действительно ли его творческая биография делится только на два этаna, а именно «диалектический» и «экзистенциально-феноменологический»? K первому Пущаев относит «относительно ранние» (Пущаев, 2018: 59) статьи «Форма превращенная» и «Анализ сознания в работах Маркса», а также

3Так, «Очерк современной европейской философии» (№ 111 в библиографии) лишь обогатил книгу одной цитатой (Пущаев, 2018: 29). Автор также цитирует, но лишь цитирует опубликованную в 2016 году переписку М. Мамардашвили и Луи Альтюссера (там же: 177). 
книгу «Формы и содержание мышления» (которая составлена из материала еще более ранних работ конца 1950-х, связанных с дискуссиями в Московском методологическом кружке, подробнее см. Хромченко, 2004, также Nemtsev, 2019). Ко второму - упомянутые лекционные курсы и «возможно» (так!) книгу «Символ и содержание сознания», которая, к сожалению, осталась полностью проигнорирована в самом исследовании. Но можно ли анализировать его философию сознания без этой книги? Вероятно, вполне можно, но тогда придется упустить целый этап в творчестве рассматриваемого автора: тесное сотрудничество с Александром Пятигорским, когда они разрабатывают свой собственный аппарат для анализа сознания, в результате чего появляется не только их совместная книга, но и откровенно забытая мамардашвиливедением, заметно отличающаяся от прочитанных в то же время лекционных курсов, герметичная «Стрела познания». В общем, обоснованная периодизация творчества Мамардашвили, учитывающая все его работы, остается задачей на будущее.

В первой главе «Общие энергии Мераба Мамардашвили и Эвальда Ильенкова» автор объясняет выбор именно этих авторов для сравнения. Ясно, что даже если они в наших глазах являются безусловными лидерами философов своего поколения, это еще не достаточное основание для историко-философского сопоставления. Ведь их философские миры «на первый взгляд имеют мало общего между собой» (Пущаев, 2018: 18). Однако на второй взгляд автор такое общее находит: (1) оба они начинали с анализа философии Маркса (и оба были тонкими знатоками логики Гегеля, добавлю я за автора), (2) они принадлежали к одному и тому же сообществу послевоенных студентов Философского факультета МГУ, поэтому (3) возможно, для них обоих характерно общее проблемное поле, «а также некий общий стиль мышления в плане принадлежности к одной той же философской, культурной и общественной эпохе» (там же: 19). Эти авторы по-человечески интересны Пущаеву: «Их философствование было наиболее ярко и суггестивно [...] оба они умел придавать непосредственный жизненно-личный смысл самым казалось абстрактным и оторванным от жизни философским формулам, тезисам и понятиям» (там же: 20). В их философии виден «жизненный, а не только познавательно-абстрактный смысл философии» (там же). Однако это не означает, «что они не могли трагически ошибаться» (там же: 21). Их ошибкам автор обещает отвести отдельную главу, но фактически он постоянно возвращается к их ошибкам и заблуждениям, в особенности во второй части книги. Юрий Пущаев 
по-настоящему увлечен их творчеством, именно поэтому он так ревностно исправляет их заблуждения: антропологические у атеиста Ильенкова и идеологические у антисоветчика Мамардашвили.

В этой же главе сразу же объясняется и «отталкивание». Мамардашвили вошел в профессиональную философию позже Ильенкова, и находился под влиянием Зиновьева, которого в тот период объединял с Ильенковым исследовательский интерес к «Капиталу» Маркса. Но уже тогда их «разъединяют [...] разные подходы к одному и тому же предмету» (Пущаев, 2018: 23). Он вошел в «Московский логический кружок», выступивший против принципиального для Ильенкова тезиса о тождестве бытия и мышления. Дальнейшая эволюция неформального философского лидерства в СССР от Ильенкова к Мамардашвили совпадает с эволюцией общества «от оттепели к застою», и тем, что «у значительной части советских философов все более популярным и знаковым философом становится Кант, а не Гегель» (там же: 25). Эту эволюцию Пущаев полагает проявлением некоего массового поворота советских философов к либерализму. Хотелось бы увидеть аргументы, доказывающие это действительно интересное историко-философское предположение. Каковы основания утверждать, что если в 1970-е Кант действительно становится более популярным философом чем Гегель, то это свидетельствует именно о проявлением обращения философов-«шестидесятников» к либерализму или является его результатом? Да, как пишет на основе библиографических исследований А. Круглов, «Количественного пика общее число публикаций о Канте на русском языке достигает в середине 70-х годов хх века, а наиболее крупные публикации - в середине 80-х годов», а затем следует некоторый спад (Круглов, 2003). В этот период были изданы переводы Канта, появились первые специальные исследования о нем. Не удивительно, что академические сотрудники получили возможность читать Канта и публиковать работы о прочитанном. Еще за десятилетие до того они такой возможности не имели. Но как это социологическое обстоятельство соотносится с собственной философской траекторией Мамардашвили и с формированием его политических взглядов? Пущаев постулирует такую связь, не вдаваясь в ее обоснование. В начале 1970-х Мамардашвили окончательно отходит от марксизма, впрочем, уже опубликовав свою главную марксоведческую статью. Но в этот же период он также «отходит» и от Гегеля, опубликовав свою ранее написанную гегелеведческую диссертацию. Для прояснения развития его взглядов в период после 1968-го, требуется 
специальное исследование, и описание ее как перехода от Гегеля к Канту и от марксизма к феноменологии кажется слишком схематичным.

Фактическое отождествление кантианства и либерализма играет существенную роль в историко-философской концепции Пущаева. На мой взгляд, оно вполне уместно как историко-философская гипотеза. Но и ей требуется какое-то историко-философское обоснование; на взгляд Пущаева, оно самоочевидно. В книге довольно много таких намеченных, но не пройденных исследовательских путей, и я постараюсь в рецензии указать на некоторые из них.

Вторая глава посвящена обоснованию тезиса о сходстве диалектики и феноменологии: различаясь по методу, они обе стремятся вернуть философии руководящую роль по отношению к науке и вообще к любому рациональному познанию. Пущаев высоко оценивает этот гносеологический оптимизм и веру в объективную научную истину (Пущаев, 2018: 36, 128). Видимо, именно абсолютная приверженность Ильенкова этому поиску оправдывает его в глазах Пущаева, пусть даже тот был коммунистом и атеистом. В этой же главе Пущаев раскрывает возможности сопоставления двух философов: (1) они обсуждают «во многом один и тот же» комплекс философских идей и вопросов феноменологии сознания, когда первый говорит о «феномене», а второйоб «абстрактном и идеальном»; (2) между ними есть «негласная перекличка», поскольку «эволюция понятия „феномен“ у Мамардашвили [...] несет в себе следы и гегелевско-марксистской традиции» (там же: 39). Поэтому, заключает он, (3) феноменологию сознания и диалектику можно сопоставить «как методы вообще, как некие самые общие исходные установки» (там же: там же; курсив автора). Раскрытию тезиса (1) посвящены следующие главы. По поводу тезиса (2) можно заметить, что хотя исследование этих следов было предметом специального интереса Юрия Пущаева, я, к сожалению, не нашел в работе доказательств сходства феноменологического метода одного и диалектической логики другого. А тезис (3) недоказуем, ведь именно из-за отличия исходных установок Мамардашвили от исходных установок Ильенкова первый и оказался среди оппонентов второго уже очень рано, во время учебы на философском факультете МГУ, и в дальнейшем ссылался в своих гегелеведческих работах исключительно на Зиновьева (Nemtsev, 2019). Да, «отталкивание» действительно имело место, но что насчет «притяжения»? Возможно, под ним подразумевается общая ценностная установка, а не методологические сходства. Ценностные 
установки в отношении к философии у обоих философов действительно близки, о чем говорил и сам Мамардашвили.

В третьей главе Пущаев переходит к анализу самой философии Мамардашвили в ее целостности. Существенным источником для него является статья А.В. Ахутина «В стране Мамардашвили», где сформулированы противоречия этой философии «между феноменом, понятым как произведение, и феноменом, понятым как символ» (Пущаев, 2018: 54). Противоречие концепта произведения (как данности) и трудового усилия, т.е. активности, которое произведение требует от человекадеятеля, становится путеводной нитью в дальнейшей реконструкции. Идея «творения» мира как постоянного усилия как будто может примирить эти противоречия (апории). С ней связан и «героизм» («странный», но все-таки героизм4) философии Мамардашвили (там же: 55). Пущаев считает, что эти противоречия обусловлены двумя важнейшими темами его философии: «феноменом» и «усилием или трудом» (там же: 91). Теме труда находится аналог в философии Ильенкова, поскольку тот писал об общественном историческом труде, а идеальное - это продукт этого труда. Пущаев пишет: «труд (или практика) стали той исходной онтологической категорией, которая в диалектической философии марксизма соединяет в себе и объект и предмет» (там же: там же $)^{5}$. Конечно, сам Ильенков пишет о деятельности, а не о труде, и не об общественной исторической практике (в марксизме эти категории не синонимичны). Недаром Ильенков писал о том, что необходимо «понять, что идеальное как общественно-определенная форма деятельности человека, рождается [...] в реальной предметной деятельности человека как действительного агента общественного производства» (Ильенков, 1974: 190). Обращение к теме деятельности только усложняет рассуждение. С одной стороны, Пущаев пишет, что у позднего Мамардашвили «бытие [...] это творящая, в том числе и субъекта, деятельность» (Пущаев,

4Замечу, что в принципе из этого героического усилия индивидуальности лицом-клицу с миром можно было бы вывести и либеральные ценности, схематически восстановив, по крайней мере, некоторые линии генезиса политической философии Мамардашвили. Этот же героизм усилия связан с самой концепцией деятельности. И вот в этом открывается возможная точка схождения в анализе идей двух рассматриваемых философов.

${ }^{5}$ Сам Ильенков разрабатывал диалектическую логику, и не саму по себе, а как «необходимую составную часть научно-материалистического мировоззрения» (Ильенков, 1974: 270). Словосочетание «диалектической философии марксизма» было бы им отвергнуто, тем более в применении к его собственной работе. Он занимался диалектичской логикой, но не отождествлял ее с философией марксизма. 
2018: 106), и так исподволь превращает этого философа в сторонника т.н. «деятельностного подхода». С другой, часто отождествляет ее с «трудом». Намечается своеобразная путаница категорий «труд», «практика» и «деятельность». Вроде бы они обозначают почти одно и то же ${ }^{6}$. Но в истории советского марксизма их сопоставление и аналитическое противопоставление было постоянной и важной темой дискуссий и исследований (The Practical Essence of Man, 2015). Тонкости их употребления были важны для самого Ильенкова и его читателей, и выбор этих категорий не случаен 7 . А когда Пущаев пишет, что «категория труда заняла такое фундаментальное место в марксизме» (Пущаев, 2018: 144, прим.), и следом пишет, что «подлинное единство мышления и мира содержится в практике [...] трудовое действие фактически на деле осуществляет тождество мышления и бытия» (там же: 144, прим.), то, если пользоваться словарем советского марксизма, речь явно идет в первом случае об общественной исторической практике, а во втором о деятельности. Впрочем, на следующей странице автор пишет уже об «особой акцентуализации практики и деятельности как первоначала в истории марксистской философии» (там же: 145). Этот фрагмент прекрасно демонстрирует терминологические тонкости, требующие специального внимания в исследованиях советской философии. Без них становится непонятно, из-за чего вообще шли тогда эти многолетние дискуссии.

Пущаев анализирует одну из них. Это заочный (т. е. посмертный) «Диалог с Эвальдом Ильенковым» о природе идеального М. Лившица. Он противопоставляет динамическое, основанное на труде (хочется написать, «деятельностное») представление об идеальном у Ильенкова, более статичным преставлениям Лившица, для которого идеальное «само» уже объективно существует в действительности. Это две альтернативные марксистские метафизики. Для одной первоначалом является материя (не зависящая от деятельности и не нуждающаяся

${ }^{6} \mathrm{~B}$ статье «Материалистическое понимание мышления как предмета логики», на которую Пущаев в основном опирается в совей реконструкции представлений Ильенкова об идеальном, тот использует понятие «деятельность» и ее производные более 100 раз, а «труд» и производные только 24 раза, в четыре раза реже (Ильенков, 1974). Эту статью Ильенков без существенных изменений включил в свою книгу «Диалектическая логика».

${ }^{7}$ Суждение, что у Мамардашвили в статье «Форма превращенная», «социальная система деятельности» это вариация того же концепта общественно-исторического труда, что и у опиравшегося на Маркса Ильенкова (Пущаев, 2018: 95), выглядит крайне рискованным, поскольку словосочетание «система деятельности»-это специальное техническое понятие советской философии того периода, и оно отнюдь не синонимична категориям Ильенкова. 
в ней), а для другой- - общественный труд, общественно-предметная деятельность» ${ }^{8}$. Кажется, что Юрий Пущаев симпатизирует, скорее, Ильенкову: диалектизм последнего обусловил его радикальный онтологический оптимизм и антропоцентризм. Одобряя, по-видимому, первый, Пущаев подвергает жесткой критике второй- дальше, в девятой главе «Ильенков и религия».

Во всех исследуемых работах Мамардашвили Пущаев выделяет единое концептуальное ядро. Это творящее движение, оно же усилие непрерывного творения, порождающее феномены, они же «врожденные идеи». При этом отношение между феноменами и творящих их усилием «в целом все равно остается недоопределенным» (Пущаев, 2018: 102). В разных работах Мамардашвили по-разному пробует определить их отношение, которое осложнено тем, что возникающее произведение это в то же время и феномен. Перечислив некоторые возникающие противоречия, Пущаев вводит дополнительное понятие феномен-форма и отмечает, что «в рассуждениях Мамардашвили то первичны феноменыформы, то внутренний труд-усилие сознания. Но что „важнее“ или первичнее в этой „двоице“, он этого явным эксплицитным образом не говорит» (там же: 110). Не говорит потому, что происхождение (можно было бы сказать, «исток») феномена на самом-то деле осмыслению не поддается. Это происхождение скрывается во взаимном порождении сторон этой «двоицы», причем в том, что феномены понимаются как нечто произведенное, Пущаев усматривает следы ранних занятий Мамардашвили диалектической логикой. Кратко сравнивая его с феноменологией Гуссерля, он приходит к выводу что Мамардашвили феноменологически «перетолковал» диалектический концепт формы и вывел феномены сознания «не из системы общественной деятельности [...] а из самого же сознания, представляя их как результат его же, сознания, деятельности, но [...] скрытой и недоступной» (там же: 112). Иными словами, диалектическая логика как бы позволила ввести в феноменологию социальность и динамический принцип (движение сознания). Здесь было бы уместно введение столь важного для позднего Мамардашвили анализа массовых «превращенных форм сознания». Пущаев констатирует выявленную им в философии Мамардашвили непостижимость и одновременно несамодостаточность феномена, и приходит к тому, что так проявляется вообще некая характерная для феноменологии сознания недоопределенность (или двусмысленность). Пущаев относит

\footnotetext{
${ }^{8}$ Так, через запятую, в тексте (Пущаев, 2018: 145).
} 
феноменологию Мамардашвили к «неклассической рациональности» (описанной им же самим). Это означает, что тот принципиально отступил от идеала абсолютной научной рациональности Гуссерля, а точнее, усилил ее «неклассические потенции», подходя к сознанию именно «нерефлексивными средствами» (Пущаев, 2018: 120; не уверен, что могу сказать, какие средства имеются в виду). Таким образом, он развил субъективизм и атехничность и отказался от стремления к универсальной истине. Так Мамардашвили одновременно не заметил собственных противоречий и переоценил возможности своей неклассической рациональности; и неслучайно поэтому он ошибся «,В политической сфере“, неточно поняв суть процессов, происходивших в перестройку, и свое место в них» (там же: 125). Таким образом, анализ феноменологии неминуемо выводит Пущаева к анализу идеологии. Но до него надо пройти через еще одну главу, которая называется «Сравнение диалектики и феноменологии сознания как методов» и должна являть собой содержательный центр всей первой части.

Оба эти философа, пишет автор книги, рассматривали свою философию как некий путь, и этот путь историчен. Следовательно, оба они так или иначе должны были мыслить себя в истории. Однако от многообещающего сопоставления историзма в философии Ильенкова и Мамардашвили Пущаев уходит. В философии Ильенкова он выявляет феноменологический момент (там же: 155, курсив автора), состоящий в том, что «за разрешением противоречия нужно обратиться к самой конкретной действительности, суметь увидетъ в ней конкретный факт, который и является разрешением данной антиномии» (там же, курсив автора). Отсюда как будто открывается прямой путь к феноменологии Мамардашвили. Проблема тут в том, что у Ильенкова вовсе не было такого простого метода разрешения диалектических противоречий 9 . Как известно, Ильенков разработал свой вариант довольно сложного метода развития противоречий. Это «метод восхождения от абстрактного к конкретному» (Ильенков, 1997). И обращение «к самой конкретной действительности» для него это лишь один из начальных шагов этого восхождения, поставляющий ученому самый начальный материал для осмысления, т. н. «абстрактно-формальное». Такое игнорирование

${ }_{9}^{9}$ Автор книги иногда их называет антиномиями. Это не вполне соответствует терминологии советского марксизма, где «антиномии» были «зарезервированы» за домаркистской диалектикой. Впрочем, типичному советскому марксисту-ленинцу странным показалось бы и то, что гегелевская идея противоречия как необходимой логической формы развития приписана Ильенкову, см. Пущаев, 2018: 162. 
основной теоретической работы Ильенкова Пущаевым я не могу для себя объяснить иначе как его увлеченностью феноменологией, и открывающейся перспективой изящного сопоставления. Но можно ли анализировать гносеологию Ильенкова без «метода восхождения»?..

Второй раздел книги посвящен политике и этике. Здесь Пущаев основное внимание уделяет Мамардашвили, опираясь при этом на его выступления и интервью 1980-х. Это период сравнительно мало известен исследователям. В этот период им уже прочитаны его самые известные современным читателям курсы, и живущий в Тбилиси в «блестящей изоляции» Мамардашвили активно включается в публичные политические дискуссии. От аполитичности предшествующих периодов он переходит к открытому провозглашению своей критической общественной позиции. Возможно, этот финальный период его творчества целесообразно рассматривать как отдельный, «политико-философский период». В это время Мамардашвили оформляет собственную политическую философию. Пущаев его не выделяет в качестве отдельного хронологического этапа, но его анализ политический взглядов позднего Мамардашвили строится иначе, чем предшествующий анализ феноменологии.

Кажется, что Юрий Пущаев пытается оспорить политические воззрения Мамардашвили, дискредитируя его, однако делает он это с позиции историко-философской критики. Он считает, что «либерализм», особенно в России, несостоятелен как политическая философия. Затем Пущаев, анализируя «либерализм» Мамардашвили, заключает, что впадение философа в эту «ересь» было фатальной, хотя и обусловленной его пониманием феноменологии, политической и этической ошибкой. Мамардашвили, согласно Пущаеву, стал жертвой манихейского «,черно-белого“ мышления» (Пущаев, 2018: 192), которое, видимо, привело его к явно тупиковому националистическому утопизму, хотя Пущаев подчеркивает, что философ дистанцировал себя от крайностей грузинского национализма. Он несколько раз напоминает читателям, что Мамардашвили «убила Грузия» (там же: 192, 194), не уточняя, как это понимать. K отличительным особенностям этой работы относится злоупотребление словом «якобы», не вполне привычным в работах историков философии: «Россия [для Мамардашвили] это якобы общество инфантильное...» (там же: 189) и пр.

Восьмая глава посвящена обзору «проблем морали в творческой философии советского времени». Но фактически ее тема шире: автор ставит перед собой задачу реконструировать этику большевизма - коммунистическую мораль жертвенного героизма. Порекомендовав читателям 
изучить работы Сталина как образцы логики и «идеологические шедевры» (Пущаев, 2018: 198), он констатирует моралистический характер марксизма как такового, и выявляет две линии развития моральной философии в советском марксизме. Одна-гегельянская (Ильенков), другая, более поздняя - кантианская (Олег Дробницкий, сам Мамардашвили). Ильенков принципиально подчиняет проблематику морали проблемам совершенствования общества и практического воплощения идеального общественного состояния - коммунизма. Пущаев считает, что на эту несамодостаточность морального Ильенков буквально «обречен логикой марксизма» (там же: 201), и поэтому сразу переходит к обсуждению самой этой логики. Несколько страниц отводится почему-то Георгу Лукачу и тому, как тот решал проблему зла, неизбежно порождаемого революционной деятельностью. Взгляды Ильенкова предложено понимать по аналогии с этическими взглядами Лукача.

Возможно, между мировоззрениями этих двух великих марксистских философов есть сходства. Пущаев приводит анекдотическое свидетельство из записок Михаила Лившица: на вопрос о том, как ему удалось столько пережить, Лукач ответил: «Ich habe keine Seele» («У меня нет души»: там же: 208). Эту фразу наверняка мог бы произнести по некоему подходящему поводу и Эвальд Ильенков. «Конечно, у Лукача душа была», спохватывается сразу же Пущаев, видимо, чтобы читатель не подумал, что автор столь подчеркнуто православных взглядов мог всерьез допустить у кого-либо отсутствие души. Между тем, если остаться в рамках его же философского дискурса, эта фраза парадоксально выражает ключевое отличие Ильенкова от Мамардашвили: один - последовательный антииндивидуалист («нет души»), другой-индивидуалист («есть душа»). Исходя из этого, они строили разные антропологии и придерживались противоположных политических философий.

По мнению автора, философия Мамардашвили представляла собой «третий этап морально-философской рефлексии в философии советского времени»: после революционно-диалектического (Лукач, Ильенков), переходного (Дробницкий) этапов последовал шаг «назад к Канту» с целью последовательного построения автономной этики (там же: 212). И именно в этой главе автор приводит свои резоны считать Мамардашвили либералом, на основании того, как Мамардашвили представлял себе оптимальное общественное устройство. Основная мысль Мамардашвили такова: социальное окружение должно способствовать воспроизводству формы, позволяющей людям быть добрыми. Такое возможно «в идеальной Европе»,- но не в «бесформенной» России. Поэтому в России 
добро в философском смысле невозможно (хотя попадаются психологически добрые люди),- и «в этом смысле Мамардашвили абсолютный западник» (Пущаев, 2018: 214). Абсолютная необходимость этической формы делает Мамардашвили сторонником «европейских» общественных институтов, то есть автоматически - по Пущаеву - философским апологетом либеральных принципов. Становится понятно, почему автор с самого начала книги называл Мамардашвили либералом без какихлибо пояснений: для него быть «западником» и критиковать Россиюзначит и быть либералом. Причем это определение как будто не нуждается ни в дальнейшем уточнении, ни в доказательстве ссылками на то, кем считал себя сам Мамардашвили.

При чтении легко заметить, что тому, как критиковал советскую действительность Мамардашвили, Пущаев уделяет больше внимания чем его политической философии, которая, как сказано выше, вообщето и сама настоятельно требует реконструкции. Цитируя его «Записи в ежедневнике» (т. е. не предназначенные для публикации самим автором дневниковые заметки), Пущаев полемизирует с ними, доказывая, что (кантианская) автономия этики в сочетании с идеалистическим «радикальным западничеством» есть признак некой испорченности автора, его заведомой, как может показаться, русофобии. Наконец, вероятно, чувствуя, что дискредитировать Мамардашвили удалось не вполне, он прибегает к аргументу ad hominem, цитирую:

В целом, нравственно ущербно,- жить среди народа, пользоваться произведенными им социальными благами, двигаться вверх по карьерной лестнице и в то же время испытывать к населению этой страны лишь презрение и отвращение. Причина этого - во многом духовное и интеллектуальное бесчувствие, духовная слепота к историческим традициям России, насколько они несут и содержат в себе позитивное содержание. Ведь именно они в том числе создали многочисленные миры национальных интеллигенций, многие из которых с приходом перестройки объединились в националистический интернационал против вырастившей их России (там же: 217).

Раскритиковав Мамардашвили, Пущаев переходит в следующей, девятой, главе к анализу отношений Ильенкова и религии. Эта тема не так проста. Сам Ильенков, будучи страстным атеистом в обычном смысле этого слова, был в то же время известен своей экзальтацией и фанатичной верой в осуществимость идеала в мире. Такие черты бывают свойственны религиозным энтузиастам. Но иногда такие люди становятся пламенными атеистами, настоящими воинствующими безбожниками. 
Что именно думал Ильенков о религии (не о Боге)? Пущаев предполагает, что исследование этих воззрений Ильенкова позволит лучше увидеть, как вообще менялось отношение к религии и религиозности у советских философов. Сначала он излагает толкование Ильенковым сущности религии в книге «Об идолах и идеалах». Подход его в крайней степени антирелигиозен. Для Ильенкова религия, с одной стороны, «запрещает веру в возможность земного совершенства человека» (Пущаев, 2018: 224), а с другой стороны «являет собой форму морально-эстетического примирения Человека с самим собой» (там же: 222), т. е. с самим собой наличным. И то, и другое для марксиста неприемлемо, поскольку лишает деятельной веры в будущее.

Однако Пущаев обнаруживает в этом отношении некоторую амбивалентность, можно даже сказать, квазирелигиозность Ильенкова. Действительно, в нем можно увидеть человека, не чуждого религиозному мировосприятию (в общем, нейтральном смысле этого слова). И это позволяет посмотреть на его мышление о диалектике под неожиданным углом: как на эсхатологию.

Ранняя статья Ильенкова «Диалектика духа» оказывается в этом случаe the usual suspect. В этом странном сочинении, столь выбивающемся из ряда других, написанных Ильенковым, возможно, проявилось влияние, оказанное на него русским космизмом (Vivaldi, 2007). Ильенков, как известно, здесь буквально прорицает самоуничтожение человеческого разума. Универсальное разумное человечество пожертвует собой ради преодоления «,тепловой смерти“ мировой материи». Так оно вернет свой долг природе, самоубийством вновь запустив цикл мирового становления, чтобы через миллиарды лет осознающая себя разумная материя неизбежно возникла бы вновь. Это эсхатологическое произведение, которое ставит вопрос о смысле существовании человечества и находит его в завершении мировой истории. Пущаев находит здесь «некую извращенность мысли», «извращенную форму жертвенности» (Пущаев, 2018: 232). Однако по отношению к чему она извращена? по отношению к «правильной» жертвенности, предписываемой православием. По Ильенкову, Природа породила разум, и разум должен будет в итоге вернуть природе этот долг (там же: 233). Можно было бы заподозрить здесь проявление мифа о вечном возвращении, некий реванш мифологического мышления. Интересно было бы понять, как мог Ильенков такое допустить. Но Пущаев просто находит здесь проявление характерного для марксизма, как он его понимает, отношения к смерти. Марксизм - это философия жизни, и занимается жизнью, а не смертью. 
Содержательно думать о смерти марксизм, по Пущаеву, отказывается. «Подчеркнутое философское невнимание к смерти» Ильенкова противопоставлено подчеркнутому вниманию к ней у Мамардашвили. Для Пущаева оно является проявлением «слепого пятна» марксизма, подталкивающего своих адептов «к неправилъной смерти» (Пущаев, 2018: 238, курсив автора). «Неправильность» состоит в невозможности для марксиста придать смысл собственной смерти в ситуации, когда невозможна ни героическая гибель в борьбе, ни участие в продуктивном изменении общества, ни легкое безболезненное умирание (Пущаев приводит пример из письма самого Ильенкова: Спиноза умер за размышлением об интересной книге). Выходом из этого философского тупика становится разочарование и пароксизм самоубийства. Так умер Ильенков. Напротив, православное христианство предлагает альтернативный путь мыслить собственную смерть. Почему же Ильенков не рассматривает эту продуктивную альтернативу?..

Десятая глава посвящена уточнению своеобразия западничества философов-шестидесятников, а именно их (гипотетической) близости к европейскому протестантизму. Это довольно неожиданный поворот темы. Ни Мамардашвили, ни Ильенков не были ни шестидесятниками, ни протестантами. Поэтому Пущаев ищет возможные «созвучия» интуиций Мартина Лютера и ранних протестантов в работах друга и соавтора Мамардашвили Эриха Соловьева. Последний не является персонажем этой книги, но он написал ряд работ о Лютере и реформации и, как до негоЛукач, подворачивается автору под руку, чтобы выдвинуть предположение о возможной «гипотетической близости к раннему протестантизму [...] пусть даже не лично самого Мамардашвили, но философов из его окружения. Работы Мамардашвили не дают материала для таких выводов» (там же: 252). Однако поскольку Мамардашвили представляется Пущаеву «либералом», а ранний протестантизм в трактовке Э. Соловьева чем-то похож на либерализм, автор полагает возможным считать, что есть «мотивы, объединяющие Мамардашвили с условно протестантским типом сознания» (там же: 250). Он намечает темы для сравнения Мамардашвили с неким обобщенным протестантизмом, в котором узнается как бы протестантизм «в целом» из (пост)советского учебника философии. По контексту понятно, что подразумевается скорее протестантизм Лютера, чем Кальвина. В частности, обращает на себя внимание принципиальная роль, отводимая «индивидуальным усилиям в работе сознания и в познании» (там же). 
Намеченное историко-типологическое сравнение, возможно, указало бы на сходство философских логик ранних протестантов и Мамардашвили. Но вместо него, Пущаев прямо называет выделенные им аспекты философии Мамардашвили «романтическими», отождествляет их с его же политическими взглядами, и ищет объяснения «романтического и утопического неприятия России как отдельной цивилизации на идейном уровне» (Пущаев, 2018: 255). Казалось бы, русофобия Мамардашвили уже была вполне объяснена выше его «нравственной ущербностью». Но теперь Пущаев обнаруживает ее онтологические корни. Дело в том, что хотя поздний Мамардашвили и апеллировал к христианству, его понимание христианства «не аутентично с православной точки зрения, поскольку является модернистским и обладает очевидными дефектами...» (там же: 256). В одной и той же главе Пущаев распознает, с оговорками, аспекты протестантизма в мышлении Мамардашвилии тут же критикует его же за неправославный образ мысли. Далее, сообщив, что «из этих преувеличенных представлений о самодостоинстве личной мысли и правах личности и вытекали его радикальные, даже нигилистические воззрения на историю России и русское православие в целом. Он не принимал дух православия...» (там же: 257), Пущаев разъясняет, что «русские смирение и покорностъ» (там же: 258, курсив автора) - это вовсе не проявления рабства, как думал Мамардашвили. Это проявление особенного равнодушия к земным делам и сосредоточенности на ином. Пущаев на шаг останавливается от отождествления православия и рабства, о котором с такой силой отвержения говорил Мамардашвили. И тут же переходит к объяснению его ошибок в понимании христианства, подразумевая под ним именно православие. Лучше всего эти ошибки было бы объяснять, предложив систематическую реконструкцию представлений Мамардашвили о христианстве. Такая реконструкция до сих пор не проведена. При этом в своих поздних лекциях и интервью Мамардашвили имеется ряд упоминаний Евангелия и христианства.

Его восприятие христианства, и в том числе- его оценка отношений христианства и «русского народа»,- отдельная историко-философская проблема. Хотя Мамардашвили, безусловно, был подчеркнуто светским мыслителем, он систематически использовал библейские символы. Представляется, однако, что цель автора именно обличить заблуждения Мамардашвили, чье представление о христианстве не совпадает со взгля- 
дами Юрия Пущаева ${ }^{10}$. А для этого нужна апология, а не исследование. Поэтому он обходится лишь несколькими цитатами Мамардашвили.

Следующая глава посвящена известной «Статье трех авторов». Пущаев сообщает важные исторические обстоятельства ее появления, на основе устного сообщения Э. Соловьева, одного из ее авторов. Он указывает, что Мамардашвили не просто был главным из трех, но проделал основной объем работы. Вторая часть статьи была полностью написана им одним. Эта статья получила статус неофициального манифеста. В ней категориальная оппозиция «классический-некласический» еще не проработана с той четкостью, какую она обретет в книге «Классический и неклассический идеалы рациональности» 1984 года (Пущаев, 2018: 266). Но уже в ней прописано важнейшее отличие неклассической философии - беноменологический сдвиг, благодаря которому философия обращается не к исследованию содержаний сознания, а к самому сознанию как событию в мире. Неклассическая философия уже исходит из того, что сознание не прозрачно и не проницаемо для познающего взгляда, в нем существуют «базисные основания, феномены», которые «экранируют сами себя» и требуют не только особых исследовательских методов, но и особой онтологии сознания. Мамардашвили вводит эту онтологию посредством понятия «сфера сознания». Пущаев упоминает ее без специального объяснения. «Сфера сознания» подробно рассматривалась Мамардашвили в совместных с Пятигорским «Трех беседах о метатеории сознания», превращенных позже в книгу «Символ и сознание». «Три беседы» появились в один творческий период со «Статьей трех авторов», хотя на другом материале. В качестве примечания, отмечу, что сравнение работ о классической и неклассической рациональности с текстами, написанными совместно с буддологом Пятигорским без такой жесткой самоцензуры, как в «Вопросах философии», позволило бы восстановить генезис философии сознания Мамардашвили во всей его сложности. Сложность мысли рассматриваемого автора, вот

${ }^{10} \mathrm{~B}$ своей рецензии на эту книгу (в целом, позитивной) Константин Антонов характеризует его вгляды так: «...автор опирается на совершенно определенный способ соединения консерватизма и православия - тот, который был предложен К. Н. Леонтьевым у нас и который на Западе имеет аналоги в лице таких мыслителей, как Ж. де Местр и Д. Кортес [...]. Радикальная критика как философской, так и политической рациональности осуществляется с опорой на идею первородного греха и вытекающий из нее своеобразный антропологический пессимизм, который эти авторы противопоставляют гуманизму и будто бы с необходимостью вытекающим из него разрушительным следствиям» (Антонов, 2019: 120) 
что остается за рамками рецензируемой книги. Частично это предопределено ограниченностью взятого для исследования набора источников.

Проблема феномена в философии Мамардашвили рассмотрена уже в первой части. Теперь автор указывает, что это «раннее» представление о феномене сознания можно найти именно в «Статье трех авторов». Здесь феномен рассматривается как «внутренняя очевидность сознания» (Пущаев, 2018: 270). На нее можно опереться, чтобы не поддаваться манипуляциям. Именно эта надежность феноменов как опоры для индивидуальных решений, личного освобождения так важна для «трех авторов». Пущаев приводит важную цитату:

Именно сопротивление по отношению ко всякому откровенному насилию над внутренними очевидностями является наиболее глубоким и существенным внутрииндивидуальным наследием предшествующей истории [...] особенностью человеческой душевной организации [...] является неспособность к адаптивной, приспособительной деградации (Мамардашвили, 2004: 180, цит. по Пущаев, 2018: 270).

Это оптимистический взгляд на возможности человеческого сознания. Но это не тот исторический оптимизм, которым вдохновлялся диалектик Ильенков. Это антиисторический оптимизм. Человек оказывается замкнут в пределах собственной внутренней территории, отгороженной от соседей, от чужого сознания. Тем самым это «новое просвещение» отказывается от ценностей универсального знания и от переустройства всего общества, и сосредотачивается на автономном индивиде. А это открывает прямой путь к многообразию «сознающих миров». И в этомто многообразии и проблема с Просвещением для Юрия Пущаева: оно приводит к провозглашению ценностей индивидуализма и многообразия, а они подозрительны. Ильенкова в таком, конечно, заподозрить невозможно, он анти-индивидуалист.

Пафос «экзистенциального спасения от неподлинного существования» (там же) характерен для всей философии сознания Мамардашвили. Уже довольно давно Эрих Соловьев предложил интерпретировать позднюю философию Мамардашвили как «экзистенциальную сотериологию», указав, что она существенно отличается от классического экзистенциализма (Соловьев, 200о). Даже в приведенной цитате прочитывается тема поиска спасения. Это не христианское посмертное спасение души. Здесь понятие «спасения» используется в обобщенном значении, которое можно было бы назвать архаическим, объединяющем в себя и религиозные и секулярные смысла: спасение как пробуждение, как обретение 
индивидуальной судьбы. Это социальная и духовная автономия, достигаемая посредством автономизации самосознания (Файбышенко, 2018). Мамардашвили пользовался понятием «спасение» наряду с одним из его любимых образов «второго рождения». Он тоже явно имеет религиозную историю, но используется уже в полностью светском рассуждении. В общем, это еще один аспект христианской генеалогии светской философии Мамардашвили. Но лишь кратко упомянув тему спасения, автор уходит в другую сторону: он демонстрирует неудачу этой «попытки спасти просвещение». Он предлагает взглянуть на современную массовую культуры, оценить совершенно мизерабельное место философии в ней, и придти к выводу, что ставка на индивидуальное мышление не оправдалась. Современные медиа и особенно интернет рассеивают человека, лишая возможности думать и жить настоящей жизнью. В целом, поворот Мамардашвили и Э. Соловьева к Канту и попытка реактуализации классики оказались неудачными. У Пущаева публицистическая критика современной культуры и критика антисоветского мировосприятия Мамардашвили оказываются связаны воедино. И то, и другое - проявление «либерального» индивидуализма, влекущего за собой обесценивание ценностей, недоверие авторитета, и явное непонимание ценности традиционного иерархически устроенного общества с сильной и по-настоящему авторитетной властью (какой и была советская власть, от которой неблагородно отвернулась вестернизованная интеллигенция).

В третьем разделе автор вновь обращается к наследию Эвальда Ильенкова. Он реконструирует историю известного Загорского эксперимента. Известно, какое большое значение Ильенков придавал своей работе вместе с А. И. Мещеряковым в Загорском интернате для слепоглухих детей. Тогда четверо подростков со множественными нарушениями зрения и слуха ${ }^{11}$ в рамках специальной исследовательской педагогической программы были подготовлены к получению высшего образования в МГУ. Пущаев реконструирует, что для самого Ильенкова понятие «эксперимент» означало возможность впервые в мире научно исследовать формирование психики. «Научным» делало его именно то, что подготовку успешно прошло сразу несколько человек, и поэтому он представлялся воспроизводимым. Ключевую роль в работе с подростками Ильенков и Мещеряков отводили предметно-разделенной предметной

${ }^{11} \mathrm{C}$ «метафизической инвалидностью», как называет ее Пущаев вслед за священником о. Львом (Аршакяном) (Пущаев, 2018: 285). 
деятельности. Ильенков видел в работе с этими детьми возможность строгого подтверждения принципиального марксистского тезиса: не язык, но практическое взаимодействие с другими людьми и созданными ими предметами порождает сознание. Автор предполагает, что Ильенков применял к проблеме слепоглухоты свою «эпистемологическую модель „метода восхождения о абстрактного к конкретному“» (Пущаев, 2018: 299), так что практическое взаимодействие с другим - это «первичная клеточка», затем «высшие психические функции» Выготского. Затем в качестве «необходимых диалектических следствий» выводятся из первичного тела-действия, т. е. взаимодействия человека с окружающим очеловеченным миром выводятся мышления и язык. Несмотря на последующую обширную цитату из статьи Ильенкова «Откуда берется ум?», эта аналогия представляется слишком вольной. Развитие понятия и развитие мышления и психики - это процессы принципиально разного характера, отождествление их можно было бы назвать «вульгарным», упрощенным марксизмом, которого сам Ильенков старался избегать. Но само по себе сопоставление метода разделенной предметной деятельности с методом восхождения неожиданное и яркое. Но это единственное обращение к методу восхождения во всем исследовании. Возможно, Пущаев полагает название «метод восхождения» метафорой.

Затем Пущаев обнаруживает, что Ильенков и Мещеряков в некотором роде скрывали тот факт, что все четыре воспитанника «не бъли слепоглухонемыми с самого рождения [...] То есть в случае с ними [...] не было и не могло быть полной подконтрольности и „прозрачности“ всех факторов воспитания и обучения» (там же: 305 , курсив автора). А это лишало эксперимент методической чистоты. Собственно, настоящего, строгого эксперимента по формированию психики и мышления не могло и быть: они оказались в интернате уже будучи подростками и пройдя определенное обучение. Это обстоятельство как будто полностью лишает работу Ильенкова научности согласно тем же критериям, которые он сам для себя установил. Ведь формирование психики каждого из этих детей в критически важный ранний период уже произошло без участия экспериментатора. «Врал ли Ильенков?», задается вопросом Пущаев. Почему он стремился создать у читателей и слушателей впечатление, что четверо участников эксперимента были слепоглухими с рождения? Именно «создать впечатление», потому что авторы эксперимента не старались это скрыть. Иногда они даже «вскользь упоминали» обратное. 
Автор выдвигает предположения о том, как объяснить это странное отношение Ильенкова и Мещерякова к принципиальным ограничениям своей работы. Во-первых, для Ильенкова принципиальным было представление о существовании некоего «ноля» психики. С него развитие психики начинается в детстве (в «раннем возрасте»), туда же она возвращается при отсутствии полноценных социальных связей. Поэтому точные подробности детства до наступления «метафизической инвалидности» несущественны, развитие в раннем возрасте иногда оказывается обратимо. Во-вторых, авторы проявили революционное нетерпение $^{12}$. Поэтому они занялись самоуговариванием, игнорируя несоответствие фактов реальности своим исходным гипотезам. На их взгляд, эксперимент был вполне удачным. Но современный аналитик его при всей его фактической успешности удачным признать не может. В этой двойственности проявилась сущностная амбивалентность «всего духа светского времени» (Пущаев, 2018: 328). В этой эпохе «плохое» тесно сплелось с «хорошим», и она в конце концов максималистски самоликвидировалась (там же: там же). А экспериментатор Ильенков действительно оказывается образцовым советским философом уже не только в интеллектуальном отношении, но и по очертаниям своего жизненного пути. Победа марксизма, обогащенного наукой, над болезнью и смертью, не удалась, но будущая победа над миром - на стороне христианства (там же: 338).

Книга завершается интересным приложением: впервые опубликованным небольшим интервью автора с А. М. Пятигорским, сделанным во время конференции в Перми в 2007 году Возможно, по замыслу автора оно призвано представить скептическое отношение Пятигорского к «поколению несбывшихся надежд». Такая характеристика этого поколения весьма созвучна отношению самого Пущаева к тем, кого он изучает. Поэтому само интервью становится авторитетным подкреплением его оценки. В нем читатель находит несколько ярких характеристик Карла Поппера и друзей самого Пятигорского. Но, пожалуй, интереснее самого интервью- авторское предисловие, представляющее собой краткую зарисовку об обстоятельствах его общения с Пятигорским.

Думается, что рецензируемая работа адекватно отражает уровень историко-философских исследований творчества Мамардашвили и Ильенкова, каким он был еше десятилетие назад. В этом ее несомненное

\footnotetext{
${ }^{12}$ Пущаев в примечании напоминает об одноименном романе Ю. Трифонова, еще раз указывая на революционные корни «Загорского эксперимента» (Пущаев, 2018: 316).
} 
достоинство как своеобразного документа эпохи. Вопрос о роли материалистической диалектики в становлении феноменологии Мамардашвили, также как и вопрос о фактическом влиянии на нее Ильенкова, прямо-таки жаждут дальнейших исследований.

\section{ЛИТЕРАTУРA}

Антонов К. М. Консервативная критика культуры как историко-философский метод : достоинства и недостатки // Вестник ПСТГУ. Серия I: Богословие. Философия. Религиоведение. - 2019. - Т. 86. - С. 113-124.

Илъенков Э.В. Диалектическая логика : очерки истории и теории. - М. : Политиздат, 1974 .

Ильенков Э. В. Диалектика абстрактного и конкретного в научно-теоретическом мышлении. - М. : РОССПЭН, 1997.

Ильенков Э.В., Коровиков В.И. Страсти по тезисам о предмете философии (1954-1955) / под ред. Е.Э. Иллеш. - М. : Издательство «Канон+», РООИ «Реабилитация», 2016.

Круглов А.Н. Философия Канта в России после 1945 года. - 2003. - URL: http://kant-online.ru/?p=681 (дата обр. 1 сент. 2019).

Мамардашвили М. К. Классический и неклассический идеалы рациональности. - М. : Логос, 2004.

Мамардашвили М. К. Беседы о мышлении. - М. : Фонд Мераба Мамардашвили, 2015.

Пущаев Ю. В. Философия советского времени : М. Мамардашвили и Э. Ильенков (энергии притяжения и отталкивания). - М. : ИНИОН РАН, 2018.

Соловъев Э. Ю. Экзистенциальная сотериология Мераба Мамардашвили Историко-философский ежегодник 1998 / под ред. Н. В. Мотрошиловой. М. : Наука, 2000. - С. 387-497.

Файбышенко В.Ю. Пустая форма и начало истории : трансцендентальная философия рождения у Мераба Мамардашвили // Философия. Журнал Высшей школы экономики. - 2018. - Т. 2, № 4. - С. 13-31.

Хромченко М. С. Диалектические станковисты. - М. : Школа культурной политики, 2004.

Nemtsev M. Y. Young Merab Mamardashvili, His Department and His Friends: Making of a Philosopher // Studies in East European Thought. - 2019. Vol. 71, no. 3. - P. 179-197.

The Practical Essence of Man : The "Activity Approach" in Late Soviet Philosophy / ed. by A. Maidansky, V. Oittinen. - Leiden, Boston : Brill, 2015.

Vivaldi G. A Commentary on Evald Ilyenkov's Cosmology of the Spirit // Stasis. 2007. - Vol. 5, no. 2. - P. 192-203. 
Nemtsev, M. Yu. 2019. "V chem oshibsya Mamardashvili i chto izvratil Il'yenkov? [Where Did Mamardashvili Go Astray and What Was Il'enkov's Perversion]: retsenziya na knigu o sovet-skoy filosofii [A Review of a Book About Soviet Philosophy]" [in Russian]. Filosofiya. Zhurnal Vysshey shkoly ekonomiki [Philosophy. Journal of the Higher School of Economics] III (4), 251-275.

Mikhail NemtseV

PhD in Philosophy, MA in Gender Studies; Associate Professor AT the Plekhanov Russian University of ECONOMICS, The Moscow International University

\title{
Where Did MamardashVili Go Astray AND What Was IL'ENKOV'S PERVERSION
}

\author{
A Review of A Book About Soviet Philosophy \\ PushchayeV, Yu. V. 2018. FILOSOFIYA SOVET'SKOGO VREMENI [PHILOSOPHY OF THE \\ SOVIET ERA]: M. MAMARDASHVILI I E. IL'YENKOV (ENERGII PRITYAZHENIYA I \\ OTTALKIVANIYA) [M. MAMARDASHVILI AND E. IL'ENKOV (ENERGIES OF GRAVITATION AND \\ REJECTION)] [IN Russian]. MOskVA [MOscow]: INION RAN \\ DOI: $10.17323 / 2587-8719-2019-4-251-275$.
}

\section{REFERENCES}

Antonov, K. M. 2019. "Konservativnaya kritika kul'tury kak istoriko-filosofskiy metod [Conservative Criticism of Culture as a Method of History and Philosophy]: dostoinstva i nedostatki [Advantages and Drawbacks]" [in Russian]. Vestnik PSTGU. Seriya I: Bogosloviye. Filosofiya. Religiovedeniye 86:113-124.

Faybyshenko, V. Yu. 2018. "Pustaya forma i nachalo istorii [Empty Form and the Beginning of History]: transtsendental'naya filosofiya rozhdeniya u Meraba Mamardashvili [Transcendental Philosophy of Nascence in Merab Mamardashvili's Works]" [in Russian]. Filosofiya. Zhurnal Vysshey shkoly ekonomiki 2 (4): 13-31.

Il'yenkov, E. V. 1974. Dialekticheskaya logika [Dialectical Logic]: ocherki istorii i teorii [Essays on History and Theory] [in Russian]. Moskva [Moscow]: Politizdat.

- 1997. Dialektika abstraktnogo i konkretnogo v nauchno-teoreticheskom myshlenii [Dialectics of the Abstract and Concrete in Scientific-Theoretical Thinking] [in Russian]. Moskva [Moscow]: ROSSP.EN.

Il'yenkov, E. V., and V. I. Korovikov. 2016. Strasti po tezisam o predmete filosofii (1954-1955) [Dispute Over Thesises About the Subject of Philosophy (1954-1955)] [in Russian]. Ed. by Ye. E. Illesh. Moskva [Moscow]: Izdatel'stvo "Kanon+" / ROOI "Reabilitatsiya".

Khromchenko, M. S. 2004. Dialekticheskiye stankovisty [Dialectical Stankovsists] [in Russian]. Moskva [Moscow]: Shkola kul'turnoy politiki.

Kruglov, A. N. 2003. "Filosofiya Kanta v Rossii posle 1945 goda [Kant's Philosophy in Russia After 1945]" [in Russian]. Accessed Sept. 1, 2019. http://kant-online.ru/?p=681.

Maidansky, A., and V. Oittinen, eds. 2015. The Practical Essence of Man: The "Activity Approach" in Late Soviet Philosophy. Leiden and Boston: Brill.

Mamardashvili, M. K. 2004. Klassicheskiy i neklassicheskiy idealy ratsional'nosti [Classic and Non-Classic Ideals of Rationality] [in Russian]. Moskva [Moscow]: Logos. 
2015. Besedy o myshlenii [Discussions on Thinking] [in Russian]. Moskva [Moscow]: Fond Meraba Mamardashvili.

Nemtsev, M. Yu. 2019. "Young Merab Mamardashvili, His Department and His Friends: Making of a Philosopher." Studies in East European Thought 71 (3): 179-197.

Pushchayev, Yu. V. 2018. Filosofiya sovet.skogo vremeni [Philosophy of the Soviet Era]: M. Mamardashvili i E. Il'yenkov (energii prityazheniya i ottalkivaniya) [M. Mamardashvili and E. Il'enkov (Energies of Gravitation and Rejection)] [in Russian]. Moskva [Moscow]: INION RAN.

Solov'yev, E. Yu. 2000. "Ekzistentsial'naya soteriologiya Meraba Mamardashvili [Existential Soteriology of Merab Mamardashvili]" [in Russian]. In Istoriko-filosofskiy yezhegodnik 1998, ed. by N. V. Motroshilova, 387-497. Moskva [Moscow]: Nauka.

Vivaldi, G. 2007. "A Commentary on Evald Ilyenkov's Cosmology of the Spirit." Stasis 5 (2): $192-203$. 